\title{
VYUŽÍVANIE JASKYNNÝCH PRIESTOROV V STARŠOM ENEOLITE NA PRÍKLADE JASKYNE CIGÁNKA II PRI RÁZTOČNE ${ }^{1}$
}

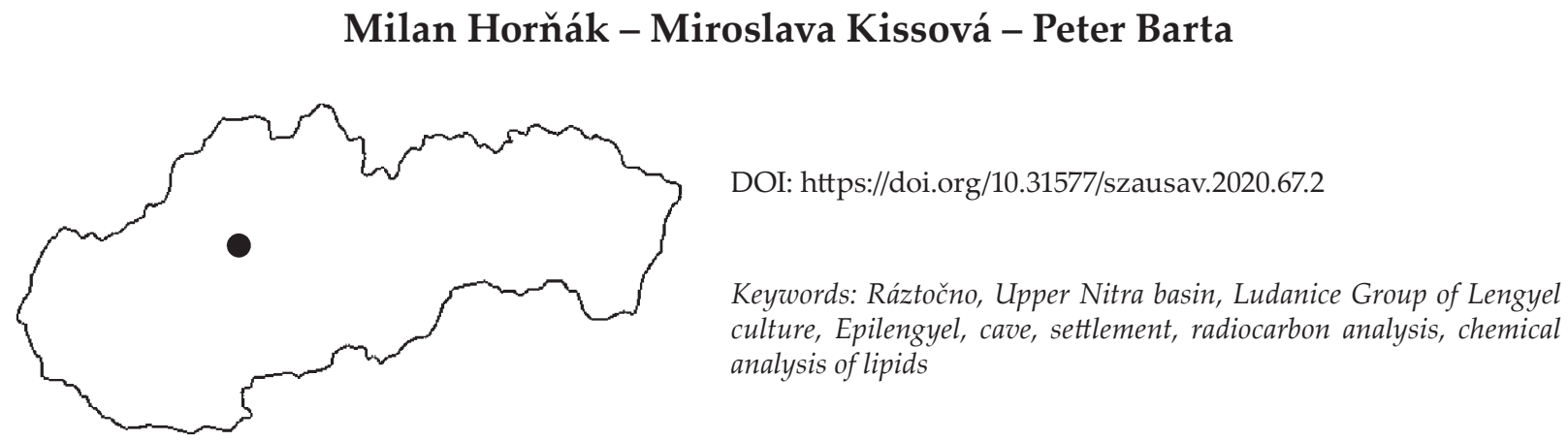

The use of cave area in the Early Eneolithic period illustrated on the example of cave Cigánka II near Ráztočno

The study deals with the analysis of pottery from the solitery finding from the cave Cigánka II near Ráztočno, localised in the mountain range Žiar in the western Slovakia. Ceramic material from this cave can be dated to the period of Ludanice Group of the Lengyel culture. Rests of carbonized food were localised in one of the vessels. It enabled examination of set of findings by scientific methods (radiocarbon dating, chemical analysis of lipids).

\section{ÚVOD}

Slovenská republika z geomorfologického hladiska predstavuje rozmanité územie s výrazným podielom krasových regiónov, ktoré sa koncentrujú predovšetkým vo vápencových a dolomitových horských oblastiach severného a stredného Slovenska. Najznámejším krasovým prejavom sú nepochybne jaskyne, priepasti či previsy. Tých je podla posledného publikovaného súpisu známych už viac ako 7200 (Bella/Hlaváčová/Holúbek 2007; SMOPaJ 2017). Z hladiska sledovanej problematiky avšak neexistuje podrobný celoslovenský súpis ${ }^{2}$ jaskýn̆ s dokladmi osídlenia v eneolite. Na základe publikovaného zoznamu jaskýň, ktorý vypracovala Slovenská správa jaskýň v roku 2007, môžeme uviest', že približne v 20-30 \% známych jaskýň boli objavené doklady o ich využití človekom v rôznych časových obdobiach (Bella/Hlaváčová/Holúbek 2007). K objavom archeologických nálezov v jaskyniach prichádza najčastejšie náhodne, predovšetkým počas neodbornej činnosti amatérskych jaskyniarov, ked’že systematickejšia výskumná rekognoskácia, až na pár výnimiek, v slovenskom vedeckom prostredí absentuje (vo všeobecnosti by sme uviedli výskumy M. Sojáka z AÚ SAV v Slovenskom krase, Slovenskom raji a v Belianskych Tatrách). Taktiež neodborným spôsobom bol členmi Oblastnej jaskyniarskej skupiny Handlová v roku 2000 nájdený zaujímavý keramický nález v jaskyni Cigánka II v katastri obce Ráztočno, okr. Prievidza. Nález bol odovzdaný na odborné spracovanie až v roku 2008, kedy bola za účasti Krajského pamiatkového úradu v Trenčíne vykonaná obhliadka miesta nálezu za účelom podrobnejšej dokumentácie.

\section{GEOMORFOLOGICKÉ VLASTNOSTI JASKÝŇ CIGÁNKA I-III}

Jaskynná lokalita Cigánka II je situovaná v juhovýchodnej časti pohoria Žiar na južnom okraji krasovej oblasti Sklenianskeho krasu, v mieste, kde sa nachádza najjednoduchší prechod z Turca do doliny riečky Handlovka (obr. 1). Medzi lokálnym obyvatel’stvom existuje pomenovanie na cestu spájajúcu obec

1 Práca vznikla z diplomovej práce M. Švihurovej pod mentorstvom M. Horňáka (Švihurová 2013) a ako dopadový ukazovatel’ udržatelnosti projektu ITMS: 26220120059.

2 Jedinou komplexnejšou archeologickou štúdiou je publikácia M. Sojáka „Osídlenie spišských jaskýň od praveku po novovek" (Soják 2007). 
Sklenné na Turci s obcou Ráztočno ležiacou na Hornej Nitre ako „Stará alebo Furmanská cesta“. Samotná jaskyňa sa nachádza v brale vrchu Bôrová (656 m n. m.) priamo nad touto cestou v blízkosti obce Ráztočno.

Z krasového hladiska je jaskyňa Cigánka II súčastou malého paleofluviálneho jaskynného systému tvoreného troma jaskyňami, resp. vetvami tohto systému známeho ako jaskyne Cigánka I-III, z ktorých každá má vlastný vchod. Geologický podklad tvoria triasové dolomity a gutensteinské vápence. Jaskynný podzemný systém vytvorený v skalnom brale predstavuje pravdepodobne pozostatok vtokového systému s eróznymi tvarmi (Lutonský 1987, 41). V odbornej literatúre venovanej krasovým javom je mož-

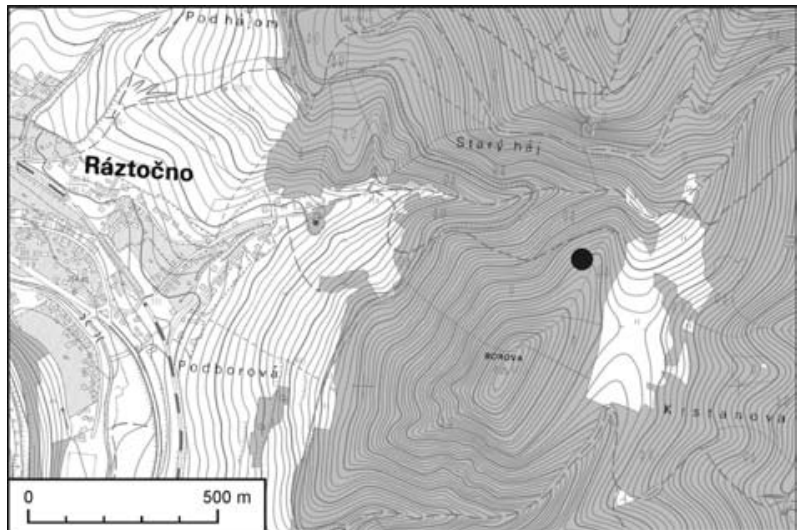

Obr. 1. Poloha sústavy jaskýň Cigánka na mape Ráztočna a okolia. né nájst prvú zmienku o jaskyni Cigánka v štúdii A. Droppu (1960, 120) o Sklenianskom krase, kde sa spomína ako jaskyňa Skalná diera v dolinke Pod skalou. Tú stotožnil M. Lutonský $(1987,42)$ s jaskyňou Cigánka. Vo svojom článku už uvádza sústavu jaskýň s vetvami Cigánka I, II a III, ktorých vchody sú situované šikmo hore okolo skalného hrebeňa (obr. 2). Amatérsky speleologický výskum zameraný na prieskum jaskyne Cigánka II prebiehal od roku 2000, kedy sa jaskyniarom z Handlovej podarilo prepojit jaskynnú vetvu II s jaskyňou Cigánka III (obr. 3; 4; Strečanský 2005, 45; Strečanský/Lutonský 2002, 11). Práve ned’aleko miesta prepojenia bola jaskyniarmi nájdená koncentrácia keramiky, ktorá je prezentovaná v tomto príspevku.

\section{JASKYŇA CIGÁNKA II A OPIS NÁLEZOVEJ SITUÁCIE}

Pre pochopenie významu a interpretačných možností objavených keramických nálezov je potrebné priblížit si podrobnejší opis pozície jednotlivých vchodov a chodieb uvedených jaskýň. Vchod do jaskyne

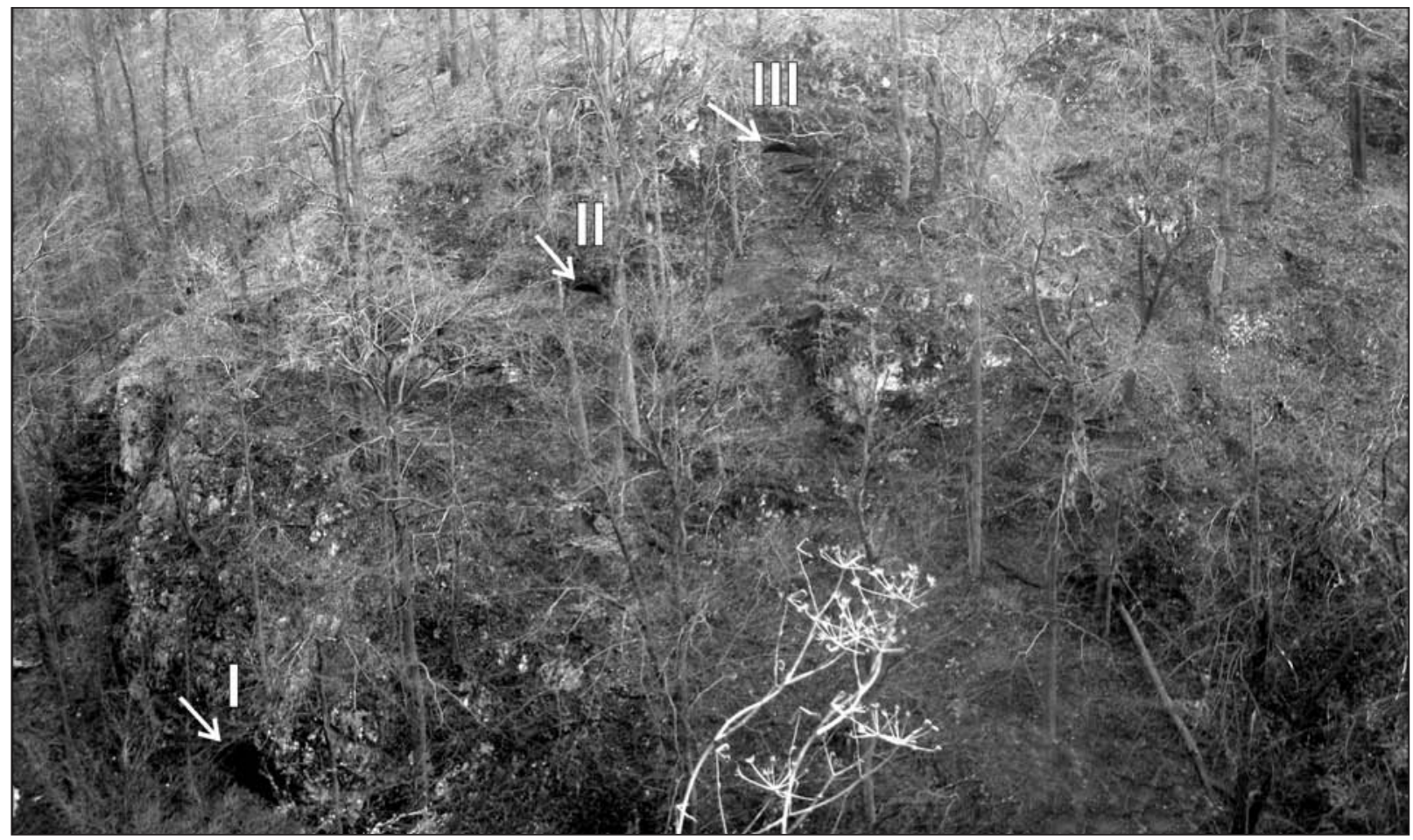

Obr. 2. Situovanie vchodov do jaskynného systému Cigánky. Foto M. Kissová. 


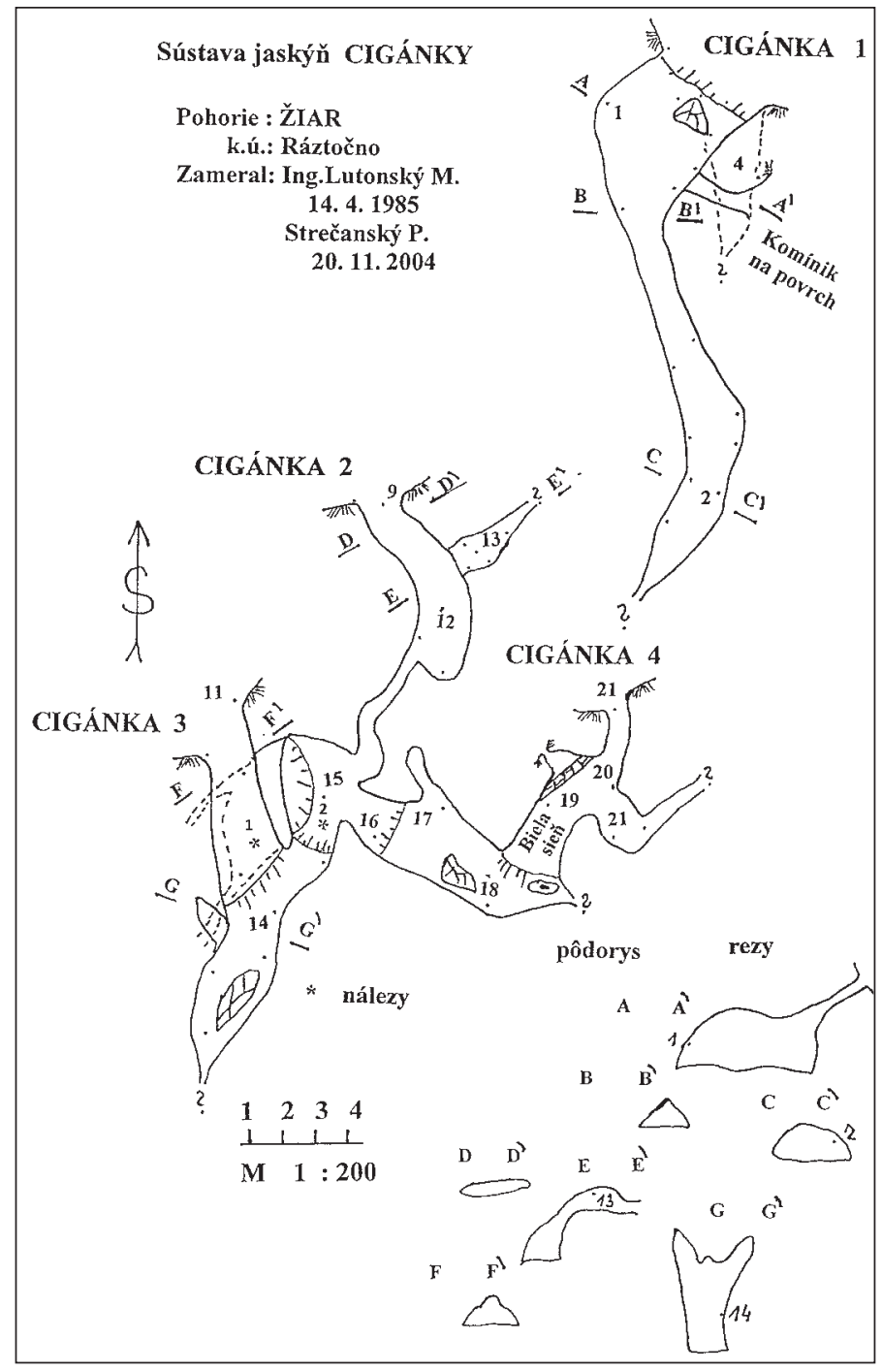

Obr. 3. Pôdorys sústavy jaskýň Cigánky (podla Strečanský 2005, 44, upravené). Miesto nálezu archeologických predmetov označené *2.

archeologickej polohe. Predpokladáme, že v čase, ked' bola jaskyňa v praveku navštevovaná, bolo treba využit na osvetlenie priestoru otvorený oheň. Na stenách sienky však nie sú viditelné stopy zadymenia. Taktiež treba uviest', že v tejto jaskyni je obmedzená cirkulácia vzduchu, čo pri dlhodobejšom pobyte spôsobí vydýchanie vzduchu s ohrozujúcimi vplyvmi na životné funkcie človeka. Vzhladom na uvedené skutočnosti sa stotožňujeme s hypotézou, že v jaskyni sa odohrávali výlučne krátkodobé aktivity.

\section{OPIS NÁLEZOV}

Z jaskyne Cigánka II bol získaný súbor obsahujúci 120 ks keramických fragmentov. Z toho však len 14 fragmentov (11, 7 \%) nieslo určitý signifikantný znak (okraje nádob, črepy s aplikovanou plastickou výzdobou v podobe výčnelkov, prípadne úch, a všetky dná alebo ich časti). Zvyšnú čast̉ nálezového fondu $(88,2$ \%) predstavovala nevýrazná keramika. Počas analýzy nálezového fondu sa podarilo čiastočne zrekonštruovat niekol'ko nasledovných typologicky určitelných fragmentov:

1. Fragment okraja nádoby s ústím mierne roztvoreným. Povrch nezdobený, hladený, sivej farby. Materiál s prímesou piesku a drobných kamienkov. Rozmery: hrúbka steny črepu $5 \mathrm{~mm}$, hrúbka okraja $4 \mathrm{~mm}$ a priemer ústia $250 \mathrm{~mm}$ (tab. I: 1).

Cigánka II, ktorý je približne 2 m široký a $0,9 \mathrm{~m}$ vysoký, je lokalizovaný približne brale (obr. 2). Prístup k nemu je možný z vrcholu brala po relatívne úzkej skalnej rímse a strmom exponovanom svahu. Prienke" s nálezmi v jaskyni II je asi $10 \mathrm{~m}$ vyššie na hornej hrane brala. Jaskyniari prekopali približne $6 \mathrm{~m}$ hlbokú intaktnými pleistocennými sedimentmi. Je teda zrejmé, že tento prechod bol v praveku nepoužitel'ný a sienka s archeologickými nálezmi bola prístupná výlučne ké nálezy boli objavené už v spomínanej malej sienke s rozmermi asi $2 \times 2 \times 1,5 \mathrm{~m}$ (obr. 5), do ktorej ústí úzka puklina s prie$4 \mathrm{~m}$, smerujúcou šikmo nahor od vchodu do jaskyne Cigánky II (obr. 3; 4, bod 15). Predpokladáme, že práve cez tento velmi tažko prechodný prístup boli prezentojaskyne. Vzhladom na to, že neexistuje adekvátna dokumentácia nálezových okolností, pri analýze archeologického materiálu sme vychádzali z informácií od nálezcov a z poznatkov, ktoré priniesla odatočná obhliadka miesta nálezu.

nálezu bol nájdený zvyšok popolovitej vrstvy, ktorá obsahovala viacero keramických fragmentov (časti ústia, dna, tela nádob). Podla vel'kosti fragmentov a spôsobu uloženia vylučujeme možnost’ premiestnenia vodou alebo zvieratami a bez pochýb môžeme uvažovat o ich primárnej 


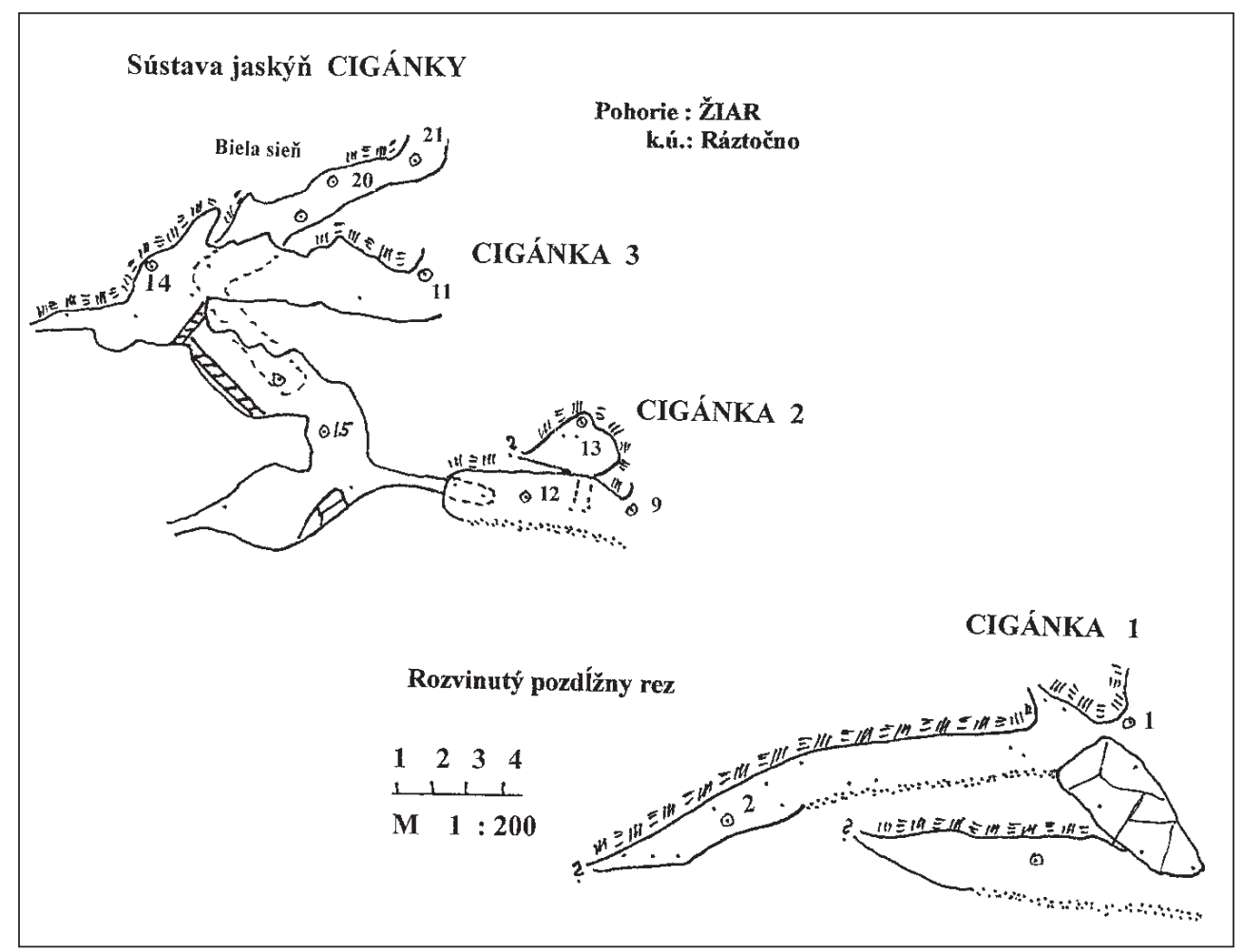

Obr. 4. Rozvinutý pozdížny rez sústavy jaskýň Cigánky (podla Strečanský 2005, 44, upravené).

2. Okrajový črep nádoby bez výzdoby. Povrch je hladený, sivej farby. Keramická hmota obsahuje anorganické ostrivo v podobe piesku a malých kamienkov. Rozmery: hrúbka steny črepu $6 \mathrm{~mm}$, hrúbka steny okraja $4 \mathrm{~mm}$, priemer ústia nádoby $250 \mathrm{~mm}$ (tab. I: 2).

3. Črep okraja nádoby s roztvoreným ústím. Povrch je bez výzdoby, čiastočne skorodovaný, sivej farby. Keramická hmota s obsahom anorganického ostriva (piesok a drobné kamienky). Rozmery: hrúbka steny črepu 5 mm, hrúbka steny okraja $4 \mathrm{~mm}$, priemer ústia nádoby $250 \mathrm{~mm}$ (tab. I: 3).

4. Fragment vrchnej časti nádoby so zachovaným okrajom, mierne rozšíreným lievikovitým hrdlom a plastickým výčnelkom umiestneným tesne nad maximálnym vydutím nádoby. Povrch tmavohnedej farby upravený hladením. Materiál s anorganickým ostrivom. Rozmery: hrúbka steny črepu $6 \mathrm{~mm}$, hrúbka okraja 4 mm, priemer ústia $130 \mathrm{~mm}$ (tab. I: 5).

5. Fragment spodnej časti nádoby s mierne odsadeným dnom. Povrch je hladený, nezdobený, sivohnedej farby. Keramická hmota obsahuje stredne zrnitú anorganickú prímes. Rozmery: hrúbka steny nádoby $6 \mathrm{~mm}$, hrúbka dna $6 \mathrm{~mm}$, priemer dna $90 \mathrm{~mm}$ (tab. I: 7).

6. Malé perforované ucho nádoby z keramickej hmoty s anorganickým ostrivom. Nezdobené s hladeným povrchom sivej farby (tab. I: 4).

7. Fragment nádoby s plastickým výčnelkom, tzv. slepým uchom. Povrch je nezdobený, hladený, hnedej farby. Keramická hmota s výrazným podielom anorganického ostriva. Hrúbka steny črepu $6 \mathrm{~mm}$ (tab. I: 6).

8. Čast’ dna a spodnej časti nádoby. Povrch bez výzdoby, hladený. Farba tmavosivá. Materiál s obsahom piesku a drobných kamienkov. Rozmery: hrúbka steny nádoby $9 \mathrm{~mm}$, hrúbka dna $9 \mathrm{~mm}$, priemer dna nádoby $170 \mathrm{~mm}$ (tab. I: 8).

9. Fragment spodnej časti nádoby s dnom. Povrch je nezdobený, hladený, tmavosivej farby. Keramická hmota s prímesou ostriva v podobe piesku a drobných kamienkov. Rozmery: hrúbka steny nádoby $9 \mathrm{~mm}$, hrúbka dna $12 \mathrm{~mm}$, priemer dna nádoby $170 \mathrm{~mm}$ (tab. I: 9).

10. Fragment spodnej časti nádoby s dnom. Povrch je nezdobený a hladený, tmavohnedej farby. V keramickom materiáli pridané anorganické ostrivo. Rozmery: hrúbka steny $6 \mathrm{~mm}$, hrúbka dna $7 \mathrm{~mm}$, priemer dna 90 mm (tab. I: 10).

11. Fragment tela nádoby s pásikovým uchom so zvislým otvorom. Povrch nezdobený, hladený. Materiál tmavosivej farby s anorganickou prímesou. Hrúbka steny $8 \mathrm{~mm}$ (tab. II: 1).

12. Fragment tela nádoby s vertikálnym pásikovým uchom, bez špecifickej výzdoby. Povrch je hladený, tmavosivej farby. Materiál premiešaný s pieskom a drobnými kamienkami. Hrúbka steny črepu 8 mm (tab. II: 2).

13. Vrchná čast’ tela hrncovitej nádoby s mierne roztvoreným ústím a zhrubnutým okrajom. Tesne nad líniou maximálneho vydutia je aplikované slepé ucho. Povrch je nezdobený a upravený hladením. Farba povrchu červenohnedá. Keramická hmota obsahuje makroskopické anorganické ostrivo. Rozmery: hrúbka steny $6 \mathrm{~mm}$, hrúbka okraja $10 \mathrm{~mm}$, priemer ústia nádoby $310 \mathrm{~mm}$ (tab. II: 3). 


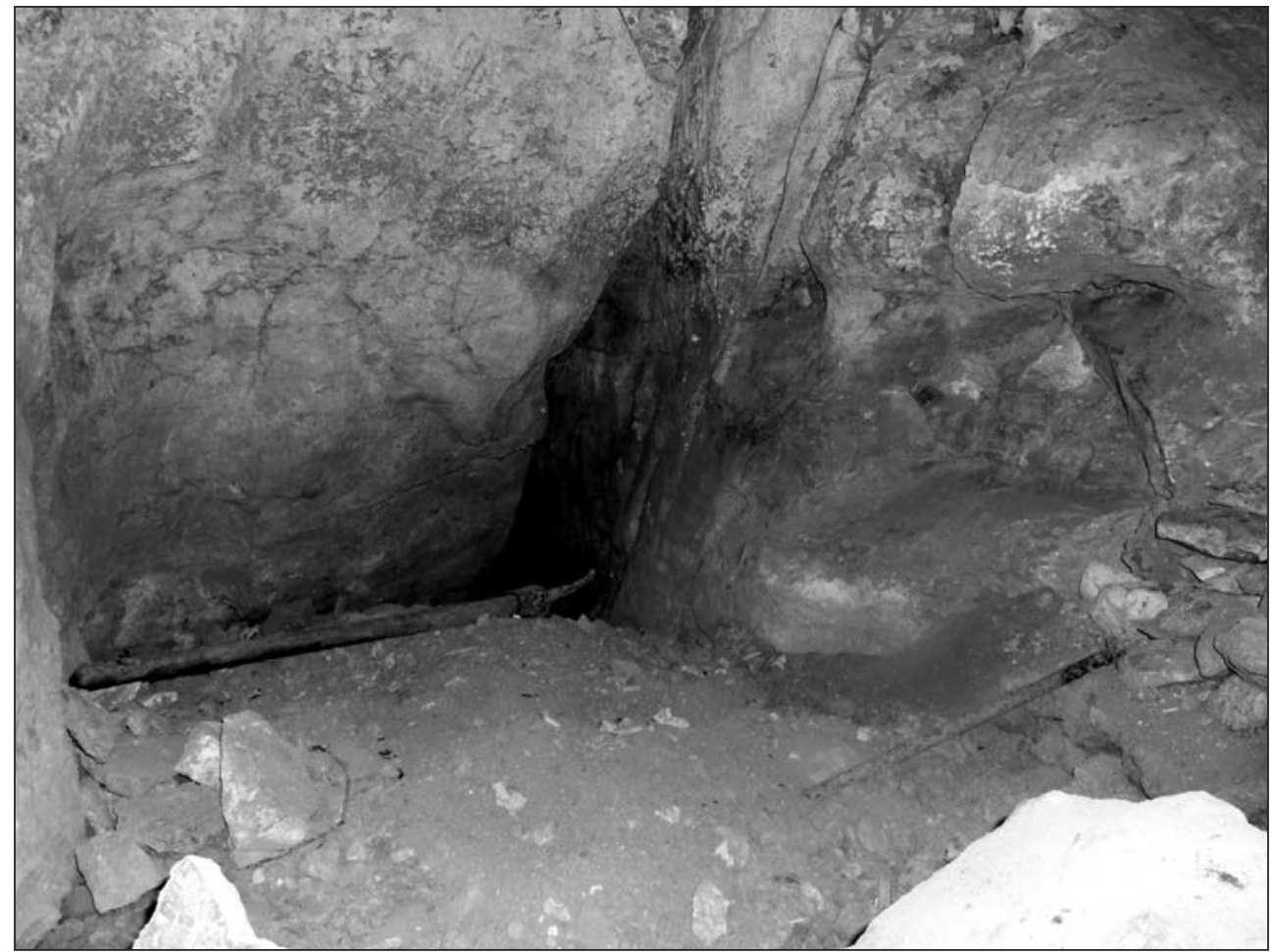

Obr. 5. Jaskyňa Cigánka II. Miesto nálezu archeologických predmetov pri dodatočnej obhliadke. Foto M. Kissová.

14. Fragment spodnej časti nádoby so zachovaným dnom (pravdepodobne spodná čast’ nádoby uvedenej pod číslom 1). Povrch bez výzdoby a hladený, červenohnedej farby. Materiál s anorganickou prímesou. Rozmery: hrúbka steny $7 \mathrm{~mm}$, hrúbka dna $10 \mathrm{~mm}$, priemer dna $125 \mathrm{~mm}$ (tab. II: 4).

15. Zvyšnú čast’ nálezového fondu dopĺn̆a 105 atypických fragmentov s hrúbkou 6-7 mm. Ich povrch neniesol žiadnu špecifickú výzdobu, bol upravený len hladením.

Skúmaný nálezový celok je možné na základe keramickej hmoty, úpravy a farby povrchu rozdelit do dvoch kategórií približne s rovnakým zastúpením fragmentov. Prvú skupinu predstavuje keramika s hladeným, nelešteným povrchom v odtieňoch od červenohnedej, cez tmavohnedú po čiernu farbu. Keramická hmota obsahuje výrazný podiel anorganických prímesí v podobe menších kamienkov. Druhú skupinu reprezentujú keramické fragmenty, ktorých povrch je taktiež upravený hladením, s výraznými stopami po hladidle, avšak oproti prvej kategórii sú viditelné rozdiely ako vo farbe črepu, ktorá sa pohybuje v odtieňoch sivej, tmavosivej až čiernej, tak aj v použitej keramickej hmote, v ktorej možno pozorovat menší podiel drobných kamienkov a piesku. Obe skupiny je možné zaradit do kategórie nádob, ktorých hrúbka steny sa pohybuje od 5 do $7 \mathrm{~mm} \mathrm{~s}$ miernym zhrubnutím v blízkosti dna a pri aplikácii pásikových úch. V keramickej hmote je badatelný výrazný podiel minerálií, ktoré ale nie sú na povrchu viditelné. Pravdepodobne je to zapríčinené spôsobom úpravy povrchu, pri ktorom dochádza k premiestneniu anorganických ostrív z povrchu smerom k jadru nádoby. Na niektorých fragmentoch nachádzame aj stopy po takomto hladení.

V súvislosti s výzdobou povrchu nádob možno povedat, že v skúmanom celku sa nevyskytla žiadna špecifická rytá či malovaná výzdoba. Črepy boli nezdobené, upravené len hladením. V niekol'kých prípadoch sa objavili fragmenty s výrazne hnedým povrchom, ktoré boli dôsledne hladené a vytvorila sa na nich jemná lesklá vrstva (tab. I: 5). Na viacerých črepoch badat’ väčšiu pozornost̉ venovanú úprave vnútorných stien nádoby, pričom sa na tieto fragmenty $\mathrm{v}$ analyzovanom celku viažu vel'ké pásikové uchá (tab. II: 1, 2). Výraznými prvkami sú taktiež plastické výčnelky v podobe malých pupčekov a tzv. slepých úch, ktoré boli aplikované nad líniou najväčšieho vydutia nádoby (tab. I: 4-6; II: 3).

Na základe zachovaných fragmentov je možné domnievat sa, že nálezový celok pozostával z troch nádob. Najvýraznejšou častou súboru je čiastočne rekonštruovatelná vrchná a spodná čast hrncovitej nádoby s mierne roztvoreným ústím červeno až tmavohnedej farby, ktorá má nad líniou maximálneho 


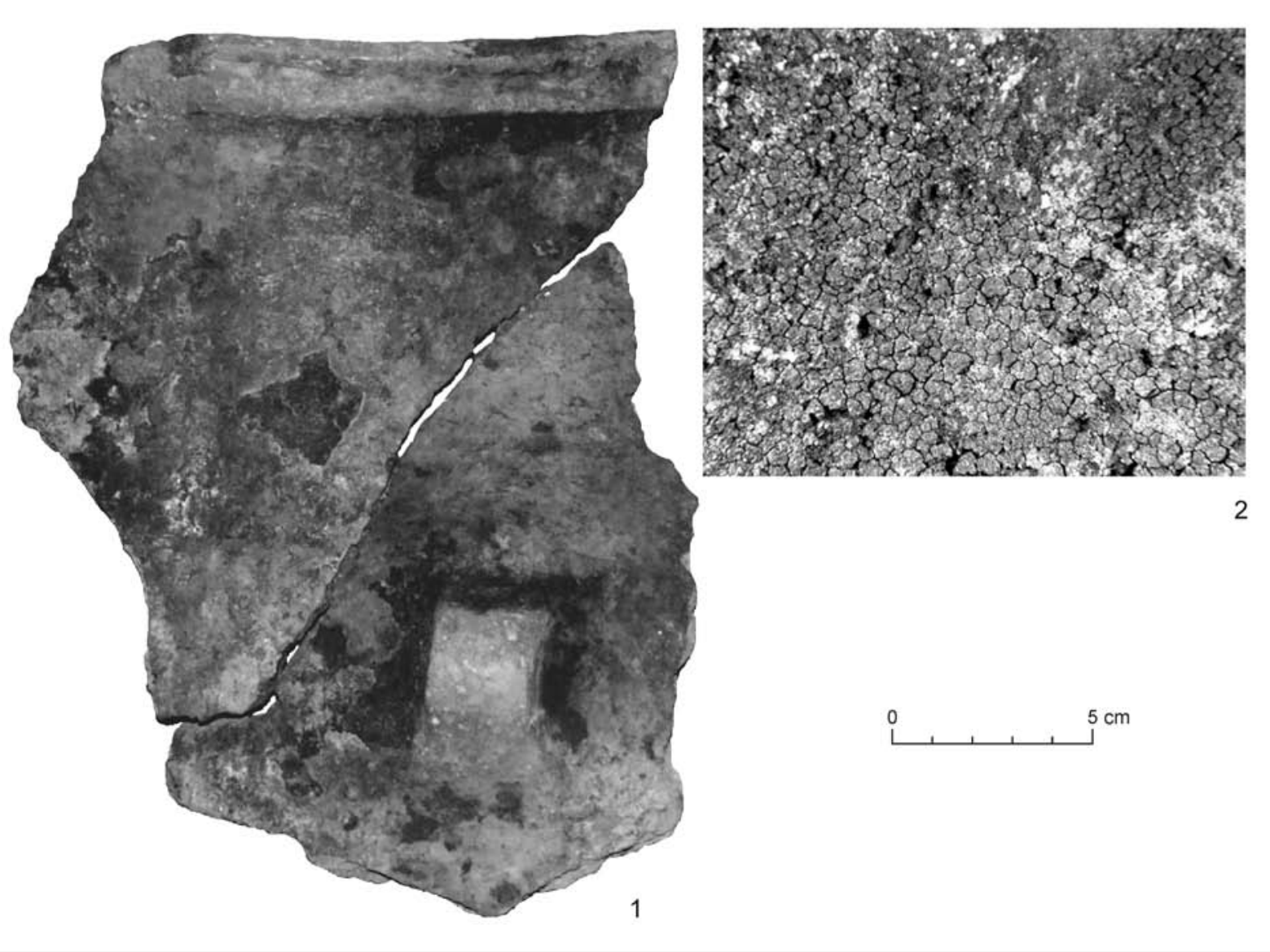

Obr. 6. Jaskyňa Cigánka II. 1 - viditel’né organické zvyšky na vonkajšom povrchu nádoby; 2 - organické zvyšky na vnútornom povrchu (zväčšené 10 x). Foto L. Soberl (1); P. Barta (2).

vydutia aplikované vertikálne slepé ucho, resp. výčnelok (tab. II: 3, 4). Je pravdepodobné, že fragment druhého slepého ucha (tab. I: 6) patrí taktiež k tejto nádobe. Bohužial', nepodarilo sa zrekonštruovat' chýbajúcu čast’ a potvrdit túto domnienku. Práve na fragmentoch z hornej časti tejto nádoby boli usadené karbonizované zvyšky potravy v podobe tvrdej, popraskanej „krusty“, ktoré poskytli vhodný materiál pre prírodovedné analýzy $\left({ }^{14} \mathrm{C}\right.$ datovanie, lipidová analýza). Dalej bola zrekonštruovaná horná čast menšej nádoby, ktorej tmavohnedý povrch bol dôsledne hladený a nad líniou maximálneho vydutia bol nanesený malý plastický „pupček“ (tab. I: 5). Zvyšný kresbovo dokumentovaný materiál, o ktorom je možné predpokladat', že na základe keramickej hmoty a úpravy povrchu pochádzal z tej istej nádoby, je príliš fragmentárny a nepodarilo sa zrekonštruovat celý tvar nádoby.

\section{ANALÝZA A DATOVANIE}

Analyzovaný črepový materiál je len málo rekonštruovatelný, ale napriek tomu poskytol dostatočné množstvo charakteristických znakov, podla ktorých je možné určit kultúrne zaradenie súboru. Zrekonštruované formy a profilácia nádob dovolujú nález zaradit do tzv. epilengyelského horizontu reprezentovaného na území juhozápadného Slovenska skupinou Ludanice (Čižmář a i. 2004, 212; Pavúk 2000, tab. I). Z relatívne blízkeho okolia predmetnej lokality sú analogické keramické nálezy známe z jaskyne Dúpna diera pri Slatinke nad Bebravou (Bárta 1983, obr. 6: 3) či z výskumu niekolkých sídliskových jám na otvorenom sídlisku v Slovenskom Pravne (Nevizánsky/Šalkovský/Zachar 2017, 41-44; Šalkovský 1977, 261, obr. 169: 10, 15). Oproti iným nálezovým celkom z Turca, Považia alebo Ponitria však analyzovaný súbor vykazuje v morfologických a výzdobných detailoch určité špecifiká. 


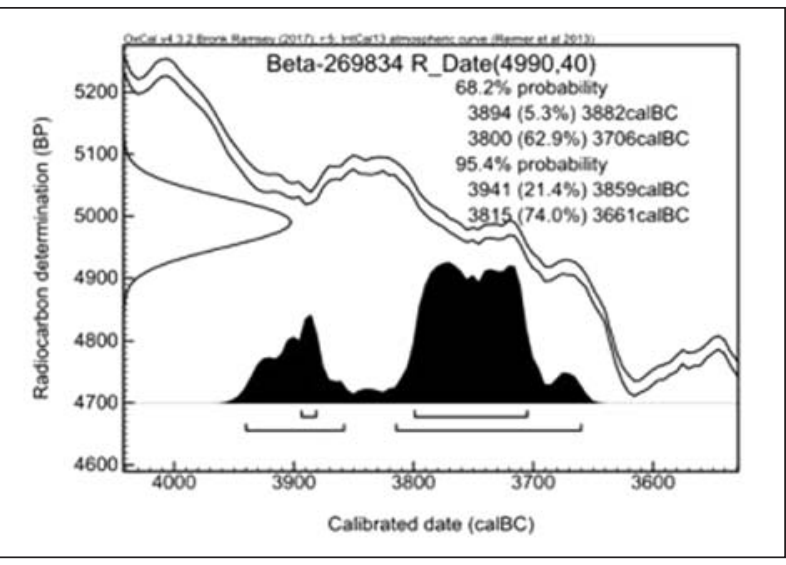

Obr. 7. Kalibrovaná hodnota konvenčného rádiouhlíkového veku nameraného na vzorke karbonizovanej organickej hmoty. Na konfidenčnej hladine 68,2 \% je vzorka datovaná do rozpätia 3894-3882 alebo 3800-3706 pred Kr., na konfidenčnej hladine 95,4 \% je datovaná do rozpätia 3941-3859 alebo 3815-3661 pred Kr.
Len v jednom prípade bola zaznamenaná aplikácia plastického výčnelku na nádobe. Ďalší rozdiel spočíva $\mathrm{v}$ uplatnení tzv. slepých úch umiestnených nad líniou najväčšieho vydutia nádoby. Analogické znaky je možné nájst’ v súboroch keramiky pochádzajúcich z Ludaníc a Branča (Lichardus/Vladár 1964, obr. 3: 8; 37: 16), či v hrobe z Čiernych Klačian (Veliačik 1975, obr. 95: 18-20; 96: 1-4). Tento sporadický výskyt „pupčekov“ je prekvapivý, ked'že na základe doposial' skúmaných celkov je aplikácia plastických výčnelkov pre ludanickú skupinu typická (Šuteková 2011, 25). Zároveň je nutné podotknút, že existujú evidentné regionálne rozdiely $\mathrm{v}$ materiálnej kultúre $\mathrm{v}$ rámci rozšírenia samotnej skupiny Ludanice medzi oblastami ako Pohronie, stredná a horná Nitra či Malé Karpaty (Pavúk/Bátora 1995, 69). Avšak na základe zachovanej plastickej výzdoby a jej sporadickom výskyte, profilácie črepov a podobnosti materiálu z iných lokalít je možné nález priradit’ do strednej až mladšej fázy skupiny Ludanice (Čižmář a i. 2004, 214; Pavúk 2000, tab. 1).

Pre overenie uvedeného datovania, získaného na základe klasickej a interpretačne limitujúcej typochronologickej metódy, sme sa rozhodli pre získanie exaktnejších chronologických dát. Využili sme skutočnost', že nádoba 1 (tab. II: 3, 4) obsahovala zvyšky karbonizovanej potravy usadenej na vonkajšej a vnútornej stene $\mathrm{v}$ hornej časti nádoby (obr. 6). Vybraný fragment sme v asistencii P. Bartu poslali na radiokarbonové datovanie (Barta 2009). Po kalibrácii (OxCal 4.3: Bronk Ramsey 2001; IntCal13: Reimer a i. 2013) nameraného konvenčného rádiouhlíkového veku (BETA-269834: $4990 \pm 40$ BP) sa ukázalo, že organická hmota, ktorú považujeme za karbonizovaný zvyšok potravy (obr. 6: 2), pochádza z obdobia 3941-3859 alebo 3815-3661 pred Kr. (95,4 \%; OxCal 4.3: Bronk Ramsey 2001; IntCal13: Reimer a i. 2013). Za pozornost’ stojí skutočnost', že mladší z uvedených intervalov (obr. 7) sa končí pred obdobím, resp. zasahuje do obdobia, ked’ sa v severnej časti Karpatskej kotliny začínajú objavovat’ súbory nálezov s keramikou zo stupňa Baden I (3700-3650 calBC; porov. Barta/Mellnerová Šuteková 2019). To otvára nové východiská pri postulovaní nových budúcich hypotéz o prežívaní spoločenstiev ludanickej skupiny v hornatých častiach stredného a západného Slovenska v čase, ked’ na území juhozápadného Slovenska sa do popredia dostáva nová kultúrna kvalita.

\section{DISKUSIA}

V stredoeurópskom priestore sa v priebehu celých l’udských dejín stretávame s využívaním jaskýň človekom. V jednotlivých obdobiach sa však odlišuje ako intenzitou využívania, tak aj povahou nálezov. Z archeologického hl'adiska je možné príčiny návštev jaskynných lokalít triedit’ podla charakteru nálezovej situácie (sídlisko, pohrebisko, kultové miesto a i.) alebo podl’a vzt’ahu medzi prírodnou charakteristikou lokality a z nej vyplývajúcich možností využitia (nedostupná poloha - refúgium, priepasti - kultové miesto atd’; Peša 2006, 49). S kultúrnou skupinou Ludanice sa spája pomerne intenzívne osídlenie, resp. využívanie jaskynných priestorov, čo sa stalo priam jej typickou črtou (Němejcová-Pavúková 1970, 148; Wiedermann 1995, 55). Paralely vo využívaní jaskýň v tomto období sú pozorované aj v súdobých kultúrach (napr. Balaton-Lasinjaa), čo podla V. Pešu $(2012,233)$ naznačuje globálnejší fenomén vo vzt’ahu človeka k jaskyni. Novšie revízne výskumy poukazujú na to, že záujem o podzemné priestory začal už v staršom, prípadne strednom stupni ludanickej skupiny (Dzeravá skala: Farkaš 2005, 69; 2013). V horských, okrajových oblastiach ludanického kultúrneho okruhu zrejme vrcholil v jej mladšej až neskorej fáze (Cigánka II; Liskovská jaskyňa: Struhár 1998; 1999; Struhár/Soják 2009).

Istú pomoc pri zodpovedaní otázok týkajúcich sa problematiky využívania jaskýň v období ludanickej skupiny môžu predstavovat’ výsledky chemickej analýzy lipidov z objavenej keramiky z jaskyne 
Cigánka II. ${ }^{3}$ Uvedená analýza umožňuje získat nové informácie o možnostiach využitia keramických nádob v minulosti. Pracuje s organickými molekulami zachytenými v mikroskopických spórach keramickej hmoty alebo taktiež s volným okom viditelnými karbonizovanými organickými zvyškami. Tie sa v podobe poréznej tmavohnedej až čiernej kôry zachovali vd’aka priaznivým a konštantným pôdnym a klimatickým podmienkam aj na vonkajšom a vnútornom povrchu nádoby 1 , uloženej v jaskyni Cigánka II (obr. 6). Výsledky chemických analýz lipidov naznačujú, že táto nádoba bola primárne pravdepodobne používaná na varenie alebo skladovanie potravín, predovšetkým mäsa prežúvavcov (kozy, ovce, hovädzí dobytok) a až následne uložená spolu s jej obsahom do jaskyne. Toto zistenie ponúka nový pohl'ad na možnosti využívania keramických nádob a na ich rôzne funkcie. Deponovaním mohli artefakty uložené v jaskyni získat’ okrem svojho primárneho účelu spoločenský význam a symbolický, resp. kultový zmysel. Predmety uložené v jaskyni tak mohli nadobudnút charakter obety neznámym božstvám neskorej doby kamennej. Bohužial', nie sme schopní archeologicky plne postihnút komplex zmien, ktoré sa udiali s keramickým súborom do dňa ich uloženia v jaskyni.

Jednou z možností, ako pristupovat k danej problematike, je pohlad na využívanie jaskynných priestorov v praveku bud’ ako na výsledok špecifického kultúrneho fenoménu, ktorý sa prejavoval iba za určitých spoločenských alebo prírodných podmienok, alebo ako na celkom bežný jav, ku ktorému dochádzalo vždy, ked' v oblasti výskytu skalných dutín žili ludia (ako útočisko počas pasenia stád, lovu alebo pri exploatácii miestnych nerastných surovín, Matoušek 1993, 13). Jaskyňa Cigánka II leží v relatívne husto osídlenej oblasti, ktorá sa prejavuje nápadnou koncentráciou lokalít z obdobia starého eneolitu v katastroch obcí Jalovec a Ráztočno (Švihurová 2014, obr. 4). Sú tu doložené rozsiahle dielne na spracovanie štiepanej industrie, vrátane jadier a suroviny, ktoré využívali miestne nerastné zdroje (Remiášová 1984, 23). Je možné, že nálezy v jaskyni Cigánka II nachádzajúcej sa v blízkosti tohto sídelno-výrobného areálu spojeného s prospekčno-spracovatelskými možnostami oblasti súvisia práve s týmto osídlením a je potrebné hladat vzájomné vztahy práve medzi nimi.

Niektorí bádatelia hladajú dôvod osídlovania jaskýň v období ludanickej skupiny v zmenách klimatických podmienok, ktoré sa mali zhoršit od predpokladaného optima na prelome neolitu a eneolitu do suchého výkyvu vrcholiaceho koncom starého eneolitu (Pavúk/Bátora 1995, 161). Autori článku sa však s takýmto tvrdením odvážia polemizovat', nakol'ko jaskyne predstavujú uzavretý klimatický systém, bez výrazného dopadu vonkajších klimatických zmien. Tie sa prejavujú výhradne iba vo vchodových častiach jaskýň. Z hladiska povrchových vôd je pre krasové územia typická ich absencia. Súvisí to s celkovou cirkuláciou vody v krasovej oblasti a priepustnostou vápencového geologického podložia. Preto niektoré jaskyne, bohaté na vodu, mohli zaujat mimoriadny význam v kontexte nadstavbovej sféry danej populácie a je možné si ich dobre predstavit ako významné podzemné svätyne, v ktorých sa odohrávali náboženské obrady a komunikácia s božstvami (Peša 2012, 233). Pri interpretácii nálezov z jaskyne Cigánka II sa skôr prikláňame k interpretačným schémam, ktoré súvisia s nadstavbovou rituálnou alebo kultovou stránkou života. K takejto hypotéze nás vedie niekol'ko už uvedených faktorov, ktoré by sme pre prehladnost̉ zhrnuli.

Na prvom mieste je to lokalizácia priestorov jaskyne, ktorá sa nachádza na značne neprístupnom mieste (malý, nenápadný vchod v skalnom brale vysoko nad údolím, exponovaný prístup, koncentrácia nádob za úzkym, dlhým tunelom v malej sieni). Deponovanie nálezov v takomto priestore sa môže spájat’ s ukladaním obety do vnútra hory, kde sídli nadprirodzeno, čím si je možné zabezpečit úspešné prekonanie náročnej prekážky. Takou sa môže zdat' hrebeň pohoria Žiar, cez ktorý je doložená miestami dodnes viditelná stredoveká cesta regionálneho významu z Ráztočna popod skalné bralo so sústavou jaskýň Cigánka smerom do Skleného. Osídlenie submontánnych oblastí stredného a severozápadného Slovenska sa dáva do súvislostí aj s vzrastajúcim dopytom po medenej rude (napríklad Slovenské Pravno-Prašnica, kde boli preskúmané objekty s hrudkami medenej trosky, Nevizánsky/Šalkovský/Zachar 2017, 41-44; Šalkovský 1977, 261, obr. 169: 10, 15; pozri aj Točík 1991, 305). Je však otázne, či by človek hladajúci nové surovinové zdroje so sebou prenášal a následne ukrýval pomerne vel'ké a neforemné keramické nádoby, aké boli objavené v jaskyni Cigánka II.

\footnotetext{
3 Analýzu vypracovala L. Šoberl (2010) z Univerzity Bristol vo Velkej Británii.
} 


\section{ZÁVER}

Jaskyne zohrávali v priebehu luudskej histórie rôzne úlohy. Každý prípad využitia jaskyne je z archeologického hladiska jedinečný a nezamenitelný. Osídlenie záviselo najmä od polohy jaskyne vo vztahu k existujúcim sídelným štruktúram a ich zázemia v krajine, ako aj od samotných predispozícií jaskynných priestorov (vel'kost vchodu jaskyne, jej vnútorné priestory, jaskynné klimatické pomery). Spôsob využitia jaskyne do určitej miery prezrádza aj jeho sociálne motívy. To môžeme doložił aj v prípade špecifického nálezu v jaskyni Cigánka II situovanej v pohorí Žiar na Slovensku. Výnimočná nálezová situácia predmetov $v$ tejto jaskyni naznačuje rituálny charakter jej využívania. Takéto tvrdenie umožňuje predovšetkým samotná nálezová situácia $\mathrm{v}$ jaskynných priestoroch, ktoré mali obmedzenú cirkuláciu vzduchu a v praveku sa do nich dalo dostat len extrémne úzkym vstupom.

Archeologické nálezy, ktoré tu boli nájdené, pozostávali z keramických fragmentov viacerých nádob. Najvýraznejšie boli fragmenty ústia z hrncovitej nádoby (tab. II: 3), na ktorej sa zachovali karbonizované zvyšky organickej hmoty. Výsledky chemickej analýzy lipidov naznačujú, že táto nádoba bola primárne pravdepodobne použivaná na varenie alebo skladovanie potravín, predovšetkým mäsa prežúvavcov (kozy, ovce, hovädzí dobytok) a až následne uložená spolu s jej obsahom do jaskyne. Prítomnost̉ organickej látky umožnila datovanie keramických fragmentov s pomocou radiokarbonovej metódy. Získaný

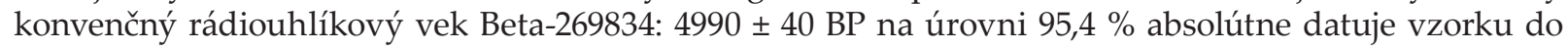
intervalov 3 941-3 859 cal BC alebo $3815-3661$ cal BC.

Cielom tohto príspevku bolo poukázat na možnosti interpretácie jedného zaujímavého nálezu z obdobia ludanickej skupiny. Zároveň sme chceli upozornit na vypovedacie možnosti priamej datácie črepového materiálu v kombinácii s lipidovými analýzami, ktoré opätovne poukazujú, že aplikovaním exaktných prírodovedných metód archeologické analýzy dostávajú novú kvalitu. 


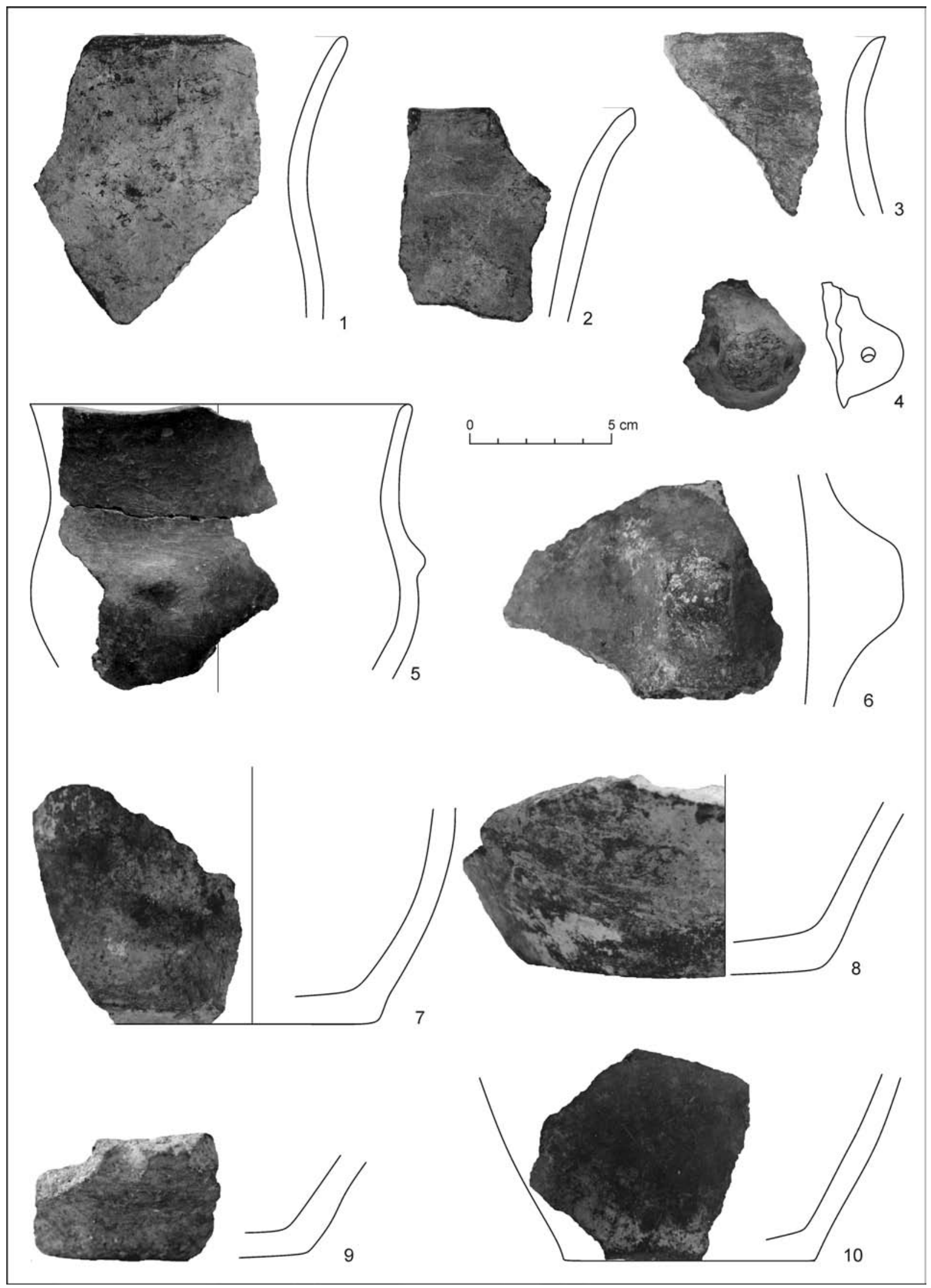

Tab. I. Jaskyňa Cigánka II. Výber keramiky. Foto a kresba M. Kissová. 


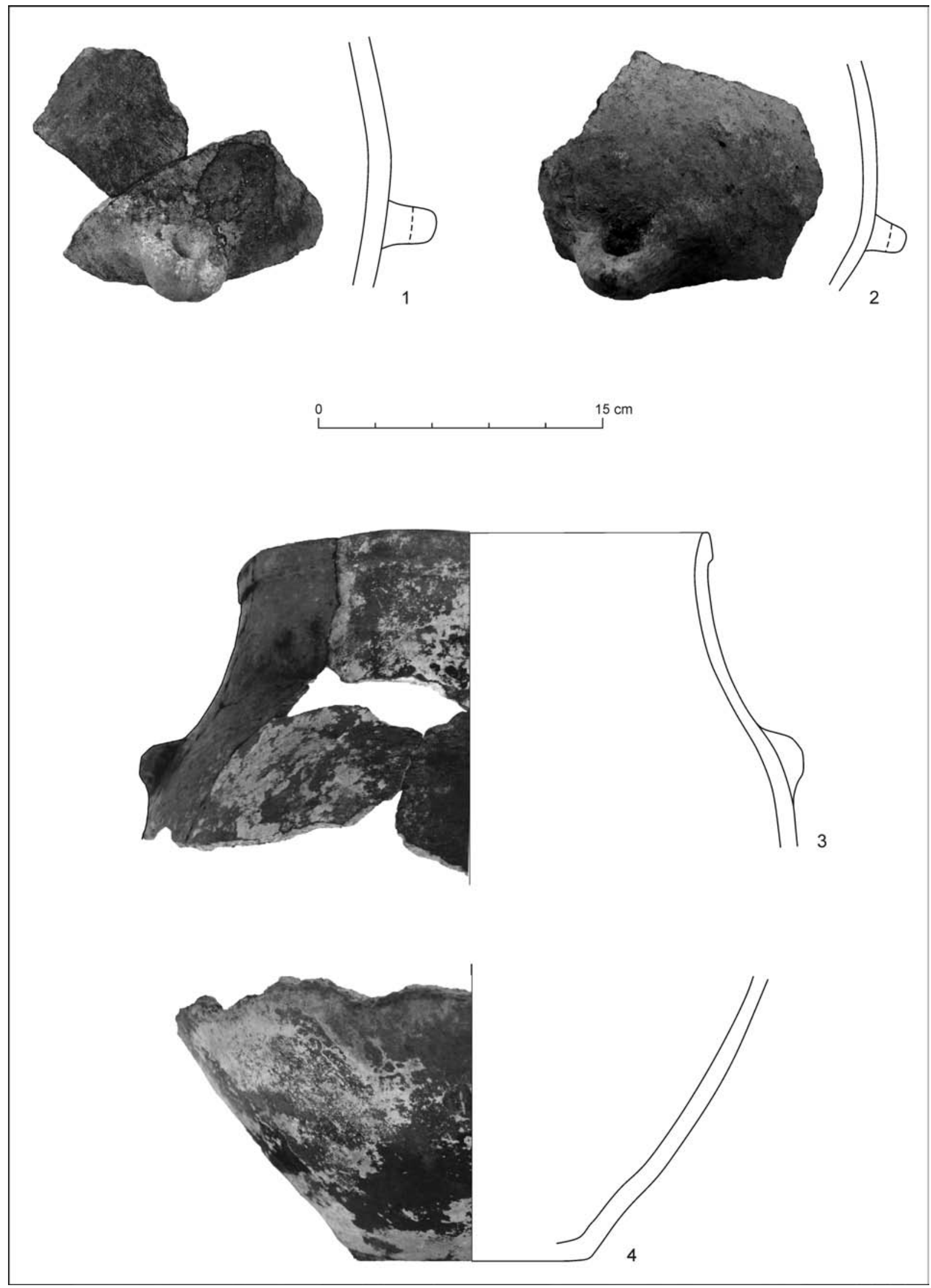

Tab. II. Jaskyňa Cigánka II. Výber keramiky. Foto a kresba M. Kissová. 


\section{LITERATÚRA}

Barta 2009

Barta/Mellnerová Šuteková 2019

Bárta 1983

Bella/Hlaváčová/Holúbek 2007

Bronk Ramsey 2001

Čižmář a i. 2004

Droppa 1960

Farkaš 2005

Farkaš 2013

Lichardus/Vladár 1964

Lutonský 1987

Matoušek 1993

Nevizánsky/Šalkovský/Zachar 2017

Němejcová-Pavúková 1970

Pavúk 2000

Pavúk/Bátora 1995

Peša 2006

Peša 2012

Reimer a i. 2013

Remiášová 1984

Soják 2007

SMOPaJ 2017

Strečanský 2005

Strečanský/Lutonský 2002
P. Barta: Správa 091209_1 o archeologicko-chronometrickom výskume vzorky zvyšku karbonizovanej potravy z jaskyne Cigánky, k. ú. Ráztočno, okr. Prievidza. Bratislava 2009. Nepublikované.

P. Barta/J. Mellnerová Šuteková: Absolute Chronology of Baden. Radiocarbon changes the narrative? Geochronometria 2, 2019, 6.

J. Bárta: Pohrebisko a praveké sídlisko v jaskyni Dúpna diera pri Slatinke nad Bebravou. Študijné zvesti Aú SAV 20, 1983, 15-37.

P. Bella/I. Hlaváčová/P. Holúbek: Zoznam jaskýň Slovenskej republiky (stav k30. 6. 2007). Liptovský Mikuláš 2007.

C. Bronk Ramsey: Development of the radiocarbon calibration program OxCal. Radiocarbon 43, 2001, 355-363.

M. Čižmář/J. Pavúk/P. Procházková/M. Šmíd: K problému definování finálního stadia lengyelské kultury. In: B. Hänsel/E. Studeníková (Hrsg.): Zwischen Karpaten und Ägäis. Neolithikum und ältere Bronzezeit. Internationale Archäologie Studia Honoraria 21. Rahden/Westf. 2004, 207-232.

A. Droppa: Krasové formy pohoria Žiar. Československý kras 12, 1960, 113-122.

Z. Farkaš: Postpaleolitické osídlenie jaskyne Dzeravá skala pri Plaveckom Mikuláši. In: I. Cheben/I. Kuzma (eds.): Otázky neolitu a eneolitu našich krajín 2004. Nitra 2005, 49-90.

Z. Farkaš: Osídlenie jaskyne Dzeravá skala v období epilengyelského horizontu. Slovenská archeológia 61, 2013, 21-91.

J. Lichardus/J. Vladár: Zu Problemen der Ludanice-Gruppe in der Slowakei. Slovenská archeológia 12, 1964, 69-162.

M. Lutonský: Krasové územie oblastnej skupiny Handlová. Spravodaj Slovenskej speleologickej spoločnosti 18, 1987, 38-44.

V. Matoušek: Nálezy lidských kostí z období neolitu až raného středověku ve středoevropských skalních dutinách. Pokus o formulaci základních problémů. In: E. Krekovič (ed.): Kultové a sociálne aspekty pohrebného rítu od najstarších čias po súčasnost'. Bratislava 1993, 11-18.

G. Nevizánsky/P. Šalkovský/T. Zachar: Archeologický výskum v Slovenskom Pravne. Príspevok k poznaniu metalurgie medi v období eneolitu. Zborník SNM v Martine. Kmetanium 14, 2017, 37-47.

V. Němejcová-Pavúková: Lengyelská kultúra (mladšie stupne s nemalovanou keramikou). In: A. Točík (red.): Slovensko v mladšej dobe kamennej. Bratislava 1970, 139-159.

J. Pavúk: Das Epilengyel/Lengyel IV als kulturhistorische Einheit. Slovenská archeológia 48, 2000, 1-26.

J. Pavúk/J. Bátora: Siedlung und Gräber der Ludanice - Gruppe in Jelšovce. Nitra 1995.

V. Peša: Využivání jeskyní v mladší době bronzové až halštatské ve vybraných oblastech střední Evropy. Památky archeologické 97, 2006, 47-132.

V. Peša: Jeskyně, člověk a krajina na příkladu neolitu a staršího eneolitu Západních Karpat. Slovenský kras 50, 2012, 225-242.

P. J. Reimer/E. Bard/A. Bayliss/J. W. Beck/P. G. Blackwell/C. Bronk Ramsey/ C. E. Buck/H. Cheng/R. L. Edwards/M. Friedrich/P. M. Grootes/T. P. Guilderson/ H. Haflidason/I. Hajdas/C. Hatté/T. J. Heaton/D. L. Hoffmann/A. G. Hogg/ K. A. Hughen/K. F. Kaiser/B. Kromer/S. W. Manning/Mu Niu/R. W. Reimer/ D. A. Richards/E. Marian Scott/J. R. Southon/R. A. Staff/C. S. M. Turney/ J. van der Plicht: IntCal13 and Marine 13 Radiocarbon Age Calibration Curves 0-50000 Years calBP. Radiocarbon 55, 2013, 1869-1887.

M. Remiášová: Najstaršie osídlenie Horného Ponitria. Vlastivedný zborník Horná Nitra 11, 1984, 9-50.

M. Soják: Osídlenie spišských jaskýň od praveku po novovek. Nitra 2007.

Slovenské múzeum ochrany prírody a jaskyniarstva: Zoznam jaskýn̆ k 31. 12. 2017. Liptovský Mikuláš 2017.

P. Strečanský: Čo nové v jaskyniach Sklenianskeho krasu. Spravodaj Slovenskej speleologickej spoločnosti 36, 2005, 44-46.

P. Strečanský/M. Lutonský: Minulost’ a prítomnost’ speleologického výskumu Sklenianskeho krasu. Spravodaj Slovenskej speleologickej spoločnosti 33, 2002, $9-14$. 
Struhár 1998

Struhár 1999

Struhár/Soják 2009

Šalkovský 1977

Šoberl 2010

Šuteková 2011

Švihurová 2013

Švihurová 2014

Točík 1991

Veliačik 1975

Wiedermann 1995
V. Struhár: Záchranný archeologický výskum a objav kultového objektu v Liskovskej jaskyni. Slovenský kras 36, 1998, 173-178.

V. Struhár: Eneolitický kolektívny hrob z jaskyne pri Liskovej, okr. Ružomberok. In: I. Kuzma (ed.): Otázky neolitu a eneolitu našich krajín 1998. Nitra 1999, 203-216.

V. Struhár/M. Soják: Liskovská jaskyňa - prehistorické sanktuárium v Chočskom pohorí. Aragonit 14, 2009, 45-50.

P. Šalkovský: Sídlisko z doby rímskej v Slovenskom Pravne. AVANS 1976, 1977, 261, 262.

L. Šoberl: Poročilo rezultatov analize organskih ostankov prazgodovinske keramike iz jame Ciganky, Slovaška. Bristol 2010. Nepublikované.

J. Šuteková: Príspevok k osídleniu dolného povodia Hrona a Ipla na začiatku eneolitu. Musaica 27, 2011, 21-30.

M. Švihurová: Sídliskové stratégie v eneolite na Hornom Ponitrí. Diplomová práca. Filozofická fakulta Univerzita Komenského v Bratislave. Bratislava 2013. Nepublikované.

M. Švihurová: Osídlenie Horného Ponitria v eneolite. Študijné zvesti AÚ SAV 56, 2014, 5-22.

A. Točík: Erforschungsstand der Lengyel-Kultur in der Slowakei. Rückblick und Ausblick. In: J. Lichardus (Hrsg.): Die Kupferzeit als historische Epoche. Symposium Saarbrücken und Otzenhausen 6.-13. 11. 1988. Teil 1. Bonn 1991, 301-317.

L. Veliačik: Záchranná akcia v Čiernych Klačanoch. AVANS 1974, 1975, 107-110.

E. Wiedermann: Höhlenfundorte und Anpassung urzeitlicher Besiedlung an die klimatischen Änderung am mittleren und oberen Flusslauf der Nitra. Studia Historica Nitriensia 4, 1995, 55-64.

\title{
The use of cave area in the Early Eneolithic period illustrated on the example of cave Cigánka II near Ráztočno
}

\author{
Milan Hor ňák - Miroslava Kissová - Peter Barta
}

Summary

Interesting ceramic finding was discovered in the cave Cigánka II, in the cadastre of Ráztočno, dist. Prievidza, by members of regional speleological group in the year 2000. Finding was handed over by founders to the specialized analysis in the year 2008, when the inspection of place of finding with the presence of representatives of the Monuments board of the Slovak republic took place to obtain the more detailed documentation.

Acquired set of findings included 120 ceramic fragments. Only 14 of these (11.7\%) had certain significant mark (rims of vessels, sherds with applied plastic decorations, and all the bottoms of their part). The rest (88.2\%) was indistinctive pottery. Typochronological analysis of material show that it is possible to date to the Epilengyel horizon, more precisely to the Ludanice group of Lengyel culture. Sherds from the mouth of pot-like vessel (Pl. II: 3) belong to the most distinct fragments, carbonized rests of organic matter were preserved on it (Fig. 6). These were examined by scientific analyses. Results of chemical analysis of lipids suggest that this vessel was primarily used to cooking or storage of food, predominantly meat of ruminants (goat, sheep, cattle) and only after that it was places together with its contents into the cave. Presence of organic matter on the surface of vessel enabled dating of pottery with the help of radiocarbon dating. Obtained conventional radiocarbon age: Beta-269834: $4990 \pm 40$ BP sample dates to the interval $3941-3859$ cal BC or $3815-3661 \mathrm{cal}$ BC at the level $95.4 \%$. Remarkable is the fact, that younger of these interval (Fig. 7) finished before, resp. reached the period when sets of findings with pottery from phase Baden I (3 700-3 $650 \mathrm{cal}$ BC) began to occur in the northern part of Carpathian basin. This starts questions about survival of communities of Ludanice group in the mountain regions of middle and western Slovakia in the time, when new cultural group comes to the forefront at the southwestern Slovakia.

Specific finding in the cave Cigánka II, situated in the mountain range Žiar, tells also something about the motives of use of cave. Exceptional finding situation of subject suggests ritual character of its usage. Such hypothesis is enabled above all by the finding situation itself in the spaces of cave which had restricted air circulation and it was possible to approach them only by extremely narrow entrance in prehistory. 
Fig. 1. The localisation of cave system Cigánka on the map of Ráztočno and its surroundings.

Fig. 2. Position of entrances to the cave system Cigánky. Photo by M. Kissová.

Fig. 3. Ground plan of the cave system Cigánky (after Strečanský 2005, 44; modified). Place where archaeological findings were found is marked by ${ }^{*} 2$.

Fig. 4. Expanded longitudinal cross-section of the cave system Cigánky (after Strečanský 2005, 44; modified).

Fig. 5. The cave Cigánka II. The place where findings were found during supplementary examination. Photo by M. Kissová.

Fig. 6. The cave Cigánka II. 1 - macroscopic organic rests on the outer surface; 2 - organic rests on the inner surface of the vessel (magnified 10x). Photo by L. Šoberl (1); P. Barta (2).

Fig. 7. Calibrated value of conventional carbon date measured on carbonised organic sample. At $68.2 \%$ confidence level the sample is dated to the range $3894-3800$ or $3800-3706$ BC, at a confidence level of $95.4 \%$ it is dated to the range 3941-3859 or 3815-3661 BC.

Pl. I. The cave Cigánka II. Pottery. Photo and drawing by M. Kissová.

Pl. II. The cave Cigánka II. Pottery. Photo and drawing by M. Kissová.

Jazyková redaktorka Miriama Nemergutová

Translated by Viera Tejbusová

doc. Dr. Milan Horňák

Oddelek za arheologijo

Filozofska fakulteta

Univerza v Ljubljani

Zavetiška 5

SI - 1000 Ljubljana

hornak.milan@gmail.com

Mgr. Peter Barta, PhD.

Katedra archeológie, Filozofická fakulta

Univerzita Komenského

Gondova 2

SK - 81499 Bratislava

peter.barta@uniba.sk
Mgr. Miroslava Kissová, PhD.

Archeologický ústav SAV Nitra

Akademická 2

SK - 94921 Nitra

miroslava.svihurova@gmail.com 